\title{
Control of Common Chickweed in Winter Wheat with Postemergence Herbicides
}

\author{
Nader Soltani*, Christy Shropshire, Peter H. Sikkema \\ University of Guelph, Ridgetown Campus, Ridgetown, Canada \\ Email: *soltanin@uoguelph.ca
}

How to cite this paper: Soltani, N., Shropshire, C. and Sikkema, P.H. (2019) Control of Common Chickweed in Winter Wheat with Postemergence Herbicides. American Journal of Plant Sciences, 10, 2012-2019.

https://doi.org/10.4236/ajps.2019.1011141

Received: October 5, 2019

Accepted: November 17, 2019

Published: November 20, 2019

Copyright $\odot 2019$ by author(s) and Scientific Research Publishing Inc. This work is licensed under the Creative Commons Attribution International License (CC BY 4.0).

http://creativecommons.org/licenses/by/4.0/

\begin{abstract}
A total of six experiments were conducted over a two-year period (2018, 2019) at the University of Guelph Ridgetown Campus to assess the efficacy of various herbicides applied postemergence (POST) for the control of common chickweed in winter wheat. Fluroxypyr/bromoxynil/MCPA, pyrasulfotole/bromoxynil, pyrasulfotole/bromoxynil/fluroxypyr, pyrasulfotole/bromoxynil/thiencarbazone, pyrasulfotole/bromoxynil/thiencarbazone + MCPA ester, tolpyralate and fluroxypyr/halauxifen + MCPA EHE, applied POST, controlled common chickweed only $5 \%-42 \%$ at 2 weeks after treatment (WAT) and $1 \%-23 \%$ at 4 WAT and resulted in common chickweed density and biomass that was similar to non-treated weedy control. Fluroxypyr/halauxifen + pyroxsulam + MCPA EHE, applied POST, provided 57\% - 82\% control of common chickweed and reduced density $93 \%$ and biomass $98 \%$ compared to the non-treated control. Thifensulfuron/tribenuron, thifensulfuron/tribenuron + MCPA ester, thifensulfuron/tribenuron + fluroxypyr + MCPA ester, tribenuron + thiencarbazone, and tribenuron + thiencarbazone + MCPA ester, applied POST, controlled common chickweed $98 \%-100 \%$ and reduced common chickweed density $96 \%-98 \%$ and common chickweed biomass $99 \%$. Based on these results, herbicide treatments which contained tribenuron including thifensulfuron/tribenuron, thifensulfuron/tribenuron + MCPA ester, thifensulfuron/tribenuron + fluroxypyr + MCPA ester, tribenuron + thiencarbazone, and tribenuron + thiencarbazone $+\mathrm{MCPA}$ ester were the most efficacious for the control of common chickweed in wheat. In addition, fluroxypyr/halauxifen + pyroxsulam + MCPA EHE, applied POST, can provide adequate control of common chickweed in winter wheat.
\end{abstract}

\section{Keywords}

Winter Wheat, Weed Control, No-Tillage, Biomass, Density, Injury, Tolerance, Yield 


\section{Introduction}

Winter wheat (Triticum aestivum L.) is one of the most widely grown cereals in Ontario [1]. In 2019, over 2,000,000 tonnes of winter wheat was produced from 406,000 ha in Ontario with a value of nearly $\$ 450,000,000$ [1]. Winter wheat production management practices have evolved over the years. In the past, Ontario winter wheat producers used conventional tillage to prepare the seedbed for winter wheat, however, in recent years many growers have changed their cropping system to no/reduced-tillage cropping practices.

No-tillage cropping production system enables producers to directly seed into standing stubble from the previous crop early in the fall, which advances the seeding date resulting in increased plant stand, winter survival and yield, thereby increasing net returns of winter wheat [2] [3] [4]. No-till practices will also improve soil physical structure, soil microbial biodiversity, and water drainage while reducing soil losses due to wind and water erosion [2] [3] [4]. Increased adoption of no-tillage cropping management system by winter wheat producers coupled with reduced usage of soil-applied residual herbicides in soybean has resulted in an increase in winter annual weeds, most importantly common chickweed (Stellaria media [L]. Vill.).

Common chickweed is a creeping annual or winter annual weed from the Caryophyllaceae family that can infest many habitats from lawns to croplands [5] [6]. The common name "common chickweed" originates from its use as bird feed for young chicks [5]. Common chickweed reproduces mainly through seeds or through leafy stems which root at the nodes allows it to spread horizontally [7]. Common chickweed stems can be prostrate, semi-erect or nearly upright, they are much branched and can be up to $50 \mathrm{~cm}$ in length. The stem is smooth with swollen nodes except for a line of hair about $1 \mathrm{~mm}$ wide which alternates from one side to the other at each node. Common chickweed leaves are opposite, the leaves are stalked near the base and stalkless at the distal ends of the stems, the leaves are small, pale green, oval-shaped with pointed tips. Common chickweed flowers are at the end of the stems and in angles between branches, the flowers have five, small (3 - $4 \mathrm{~mm}$ ), lobed, star-like white petals [8] [9]. Common chickweed generally germinates in the fall or late winter through seeds and flowers in the spring and summer before seed release and dying as the temperature rises [8] [9]. A single common chickweed plant can produce up to 20,000 seeds which can germinate and emerge from depths of up to $2 \mathrm{~cm}$ [7].

Common chickweed can grow profusely in poor, compacted and moist soils, and under shady areas below taller plants such as winter wheat [8]. It is a very competitive weed with the winter wheat crop and can cause significant losses in seed quality and yield. Farahbakhsh et al. [10] reported up to $32 \%$ yield loss in winter wheat due to common chickweed interference at densities of 20,40, 80 and 160 plants $\cdot \mathrm{m}^{-2}$. Vrabel [11] reported a potential net monetary loss of $\$ 32.75$ to $\$ 51.87 \mathrm{ha}^{-1}$ when common chickweed was not adequately controlled in winter wheat. Common chickweed can also release water-soluble phenolic biochemicals 
that can cause allelopathic interference to seedling growth of wheat [6]. Common chickweed has also been shown to be a host for non-beneficial insects and virus diseases of crops that can be conveyed through its seed [7] [9] [12]. Therefore, it is critical for winter wheat growers to adequately control common chickweed within their production system to be competitive in the global marketplace.

Thifensulfuron/tribenuron, thifensulfuron/tribenuron + MCPA ester, thifensulfuron/tribenuron + fluroxypyr + MCPA ester, fluroxypyr/bromoxynil/MCPA, pyrasulfotole/bromoxynil, pyrasulfotole/bromoxynil/fluroxypyr, pyrasulfotole/bromoxynil/thiencarbazone, pyrasulfotole/bromoxynil/thiencarbazone $+\mathrm{MCPA}$ ester, tribenuron + thiencarbazone, tribenuron + thiencarbazone $+\mathrm{MCPA}$ ester, tolpyralate, fluroxypyr/halauxifen + MCPA EHE, and fluroxypyr/halauxifen + pyroxsulam + MCPA EHE are postemergence (POST) herbicides that have potential to control common chickweed in winter wheat [13]. There is limited efficacy data on these POST herbicides for the control of common chickweed under Ontario environmental conditions.

The objective of this research was to evaluate the efficacy of thifensulfuron/tribenuron, thifensulfuron/tribenuron + MCPA ester, thifensulfuron/tribenuron + fluroxypyr + MCPA ester, fluroxypyr/bromoxynil/MCPA, pyrasulfotole/bromoxynil, pyrasulfotole/bromoxynil/fluroxypyr, pyrasulfotole/bromoxynil/thiencarbazone, pyrasulfotole/bromoxynil/thiencarbazone + MCPA ester, tribenuron + thiencarbazone, tribenuron + thiencarbazone $+\mathrm{MCPA}$ ester, tolpyralate, fluroxypyr/halauxifen + MCPA EHE, and fluroxypyr/halauxifen + pyroxsulam + MCPA EHE, applied POST, at the manufacturer's label rate for the control of common chickweed in winter wheat.

\section{Material and Methods}

Three field experiments were conducted in 2018 and 2019 (total of six experiments) at the University of Guelph Ridgetown Campus, Ridgetown, ON $\left(42^{\circ} 26^{\prime} \mathrm{N}, 81^{\circ} 53^{\prime} \mathrm{W}\right)$. The soil for the study sites was a Watford (Grey-Brown Brunisolic, mixed, mesic, sandy and imperfectly drained)-Brady (Gleyed Brunisolic Grey-Brown Luvisol, mixed , mesic, sandy and imperfectly drained) with $53 \%$ sand, $33 \%$ silt, $14 \%$ clay, $4.0 \%$ O.M. and $\mathrm{pH}$ of 6.3 in 2018 ; and $55 \%$ sand, $31 \%$ silt, $14 \%$ clay, $4.5 \%$ O.M. and pH of 6.3 in 2019.

Experiments were arranged in a randomized complete block design with three replications. Treatments included a weedy control and thifensulfuron/tribenuron, thifensulfuron/tribenuron + MCPA ester, thifensulfuron/tribenuron + fluroxypyr + MCPA ester, fluroxypyr/bromoxynil/ MCPA, pyrasulfotole/bromoxynil, pyrasulfotole/bromoxynil/fluroxypyr, pyrasulfotole/bromoxynil/thiencarbazone, pyrasulfotole/bromoxynil/thiencarbazone + MCPA ester, tribenuron + thiencarbazone, tribenuron + thiencarbazone + MCPA ester, tolpyralate, fluroxypyr/halauxifen + MCPA EHE, and fluroxypyr/halauxifen + pyroxsulam + MCPA 
EHE, applied POST, at rates listed in Table 1 . Plots were $2 \mathrm{~m}$ wide by $8 \mathrm{~m}$ long. Winter wheat "Pioneer 25R40" (DuPont Pioneer, Mississauga, ON) was seeded with a double-disc drill at $152 \mathrm{~kg} \cdot \mathrm{ha}^{-1}$ in rows spaced $19 \mathrm{~cm}$ apart at a depth of 3 cm on October 20, 2018, and October 24, 2019.

Herbicides were applied POST (separated in time each year) in the spring at Zadoks stage 22 to 32 [14] with a $\mathrm{CO}_{2}$ pressurized backpack sprayer calibrated to deliver $200 \mathrm{~L} \cdot \mathrm{ha}^{-1}$ aqueous solution at $241 \mathrm{kPa}$. The boom was $1.5 \mathrm{~m}$ long with four Hypro ULD120-02 nozzle tips (Hypro, New Brighton, MN, USA) spaced 50 $\mathrm{cm}$ apart producing a spray width of $2.0 \mathrm{~m}$.

Visible winter wheat injury [at 1,2 and 4 weeks after POST herbicide treatment (WAT)] and common chickweed control (at 2 and 4 WAT) were assessed on a scale of 0 to $100(0=$ no visible injury/no control and $100=$ plant death/total control). At $4 \mathrm{WAT}$, common chickweed density (plant $\cdot \mathrm{m}^{-2}$ ) and biomass $\left(\mathrm{g} \cdot \mathrm{m}^{-1}\right.$; dried at $60^{\circ} \mathrm{C}$ for 48 hours) were recorded from two randomly selected half-meter quadrats in each plot.

Data were analyzed using Proc GLIMMIX in SAS [15]. Herbicide treatment was the fixed effect, and environment (site-year), replicate within the environment and the treatment by environment interaction were random effects. Data from all six environments were pooled for analysis to be able to identify the most effective herbicide treatments for common chickweed control under Ontario environmental conditions. The best distribution was chosen by comparing residual plots, Pearson chi-square/df, and the Shapiro-Wilk statistic from among the appropriate potential distributions for each variable. Visual estimates of common chickweed control were arcsine square-root transformed prior to analysis with the Gaussian distribution. Common chickweed density and dry biomass were analyzed using the lognormal distribution. The non-treated weedy control, assigned a value of zero, was excluded from the analysis but treatment means were still compared to the value zero using the P-value included in the LSMEAN output. Pairwise comparisons were subjected to Tukey's adjustment prior to determining treatment differences at a significance level of 0.05. Treatment means were back-transformed for presentation and a correction for log bias was applied to chickweed density and dry biomass means.

\section{Results and Discussion}

At 1, 2 and 4 WAT, there was no visible winter wheat injury from the herbicide treatments evaluated (data not presented).

Among treatments evaluated, herbicide mixtures that included tribenuron provided the most consistent control of common chickweed in winter wheat (Table 1). Thifensulfuron/tribenuron, thifensulfuron/tribenuron + MCPA ester, thifensulfuron/tribenuron + fluroxypyr + MCPA ester, tribenuron + thiencarbazone, and tribenuron + thiencarbazone + MCPA ester, applied POST, controlled common chickweed $98 \%-100 \%$ and reduced common chickweed density $96 \%-98 \%$ and common chickweed biomass $99 \%$ at 4 WAT (Table 1 ). 
Table 1. Common chickweed control 2 and 4 weeks after herbicide application (WAT), density and dry biomass 4 WAT for herbicides applied postemergence in winter wheat at 6 sites near Ridgetown, Ontario, Canada in 2018 and 2019.

\begin{tabular}{|c|c|c|c|c|c|}
\hline \multirow[b]{2}{*}{ Herbicide treatment } & \multicolumn{4}{|c|}{$\begin{array}{l}\text { Common chickweed } \\
\text { control (\%) }\end{array}$} & \multirow[b]{2}{*}{$\begin{array}{c}\text { Common } \\
\text { chickweed dry } \\
\text { biomass }\left(\mathrm{g} \cdot \mathrm{m}^{-1}\right)\end{array}$} \\
\hline & $\begin{array}{c}\text { Rate } \\
\left(\mathrm{g} \cdot \mathrm{ai}^{-h^{-1}}\right)\end{array}$ & 2 WAT & 4 WAT & $\begin{array}{c}\text { Common } \\
\text { chickweed } \\
\text { density (plants } \cdot \mathrm{m}^{-2} \text { ) }\end{array}$ & \\
\hline Non-treated weedy control & & $0 \mathrm{~g}$ & $0 \mathrm{e}$ & $9.5 \mathrm{~b}$ & $74.2 \mathrm{c}$ \\
\hline Thifensulfuron-ethyl/tribenuron-methyl ${ }^{1}$ & 15 & $81 \mathrm{a}$ & $98 \mathrm{ab}$ & $0.4 \mathrm{a}$ & $1.1 \mathrm{a}$ \\
\hline $\begin{array}{l}\text { Thifensulfuron-ethyl/tribenuron-methyl + MCPA } \\
\text { ester }^{\text {a }}\end{array}$ & $15+280$ & $75 \mathrm{ab}$ & $99 \mathrm{ab}$ & $0.3 \mathrm{a}$ & $0.7 \mathrm{a}$ \\
\hline $\begin{array}{l}\text { Thifensulfuron-ethyl/tribenuron-methyl + } \\
\text { fluroxypyr + MCPA ester }\end{array}$ & $15+70+280$ & $75 \mathrm{ab}$ & $99 \mathrm{ab}$ & $0.4 \mathrm{a}$ & $0.5 \mathrm{a}$ \\
\hline Fluroxypyr/bromoxynil/MCPA & 600 & $26 \mathrm{de}$ & $12 \mathrm{~cd}$ & $5.5 \mathrm{~b}$ & $22.1 \mathrm{c}$ \\
\hline Pyrasulfotole/bromoxynil ${ }^{2}$ & 205 & 15 ef & $7 \mathrm{~cd}$ & $6.1 \mathrm{~b}$ & $18.0 \mathrm{abc}$ \\
\hline Pyrasulfotole/bromoxynil/fluroxypyr & 277 & $25 \mathrm{de}$ & $11 \mathrm{~cd}$ & $7.1 \mathrm{~b}$ & $19.2 \mathrm{bc}$ \\
\hline Pyrasulfotole/bromoxynil/thiencarbazone-methyl ${ }^{\mathrm{b}}$ & 211 & $33 \mathrm{~cd}$ & $11 \mathrm{~cd}$ & $7.0 \mathrm{~b}$ & $22.2 \mathrm{c}$ \\
\hline $\begin{array}{l}\text { Pyrasulfotole/bromoxynil/thiencarbazone-methyl + } \\
\text { MCPA ester }\end{array}$ & $211+280$ & $42 \mathrm{~cd}$ & $21 \mathrm{c}$ & $9.0 \mathrm{~b}$ & $18.0 \mathrm{bc}$ \\
\hline Tribenuron-methyl + thiencarbazone-methyl ${ }^{\mathrm{b}}$ & $7.5+5$ & 87 a & $99 \mathrm{ab}$ & $0.3 \mathrm{a}$ & $0.8 \mathrm{a}$ \\
\hline $\begin{array}{l}\text { Tribenuron-methyl + thiencarbazone-methyl + } \\
\text { MCPA ester }\end{array}$ & $7.5+5+280$ & 85 a & $100 \mathrm{a}$ & $0.2 \mathrm{a}$ & $0.6 \mathrm{a}$ \\
\hline Tolpyralate $^{3}$ & 40 & $5 \mathrm{f}$ & $1 \mathrm{de}$ & $7.0 \mathrm{~b}$ & $42.2 \mathrm{c}$ \\
\hline Fluroxypyr/halauxifen + MCPA EHE & $82+372$ & $28 \mathrm{de}$ & $23 c$ & $8.1 \mathrm{~b}$ & $22.3 \mathrm{c}$ \\
\hline $\begin{array}{l}\text { Fluroxypyr/halauxifen + pyroxsulam + MCPA } \\
\text { EHE }^{3}\end{array}$ & $82+15+372$ & $57 \mathrm{bc}$ & $82 \mathrm{~b}$ & $0.7 \mathrm{a}$ & $1.7 \mathrm{ab}$ \\
\hline
\end{tabular}

Note: Means within a column followed by the same lowercase letter do not differ significantly according to Tukey's HSD at $P<0.05$. ${ }^{1}$ Included non-ionic surfactant at $0.2 \% \mathrm{v} / \mathrm{v}$. ${ }^{2}$ Included ammonium sulfate at $1 \mathrm{~L} / \mathrm{ha} .{ }^{3}$ Included methylated seed oil at $0.5 \% \mathrm{v} / \mathrm{v}$ and $28 \%$ UAN at $2.5 \% \mathrm{v} / \mathrm{v}$. ${ }^{4}$ Included non-ionic surfactant at $0.25 \% \mathrm{v} / \mathrm{v}$. 
ron + metribuzin and mesosulfuron + metribuzin in winter wheat under Pennsylvania, USA environmental conditions [16]. Additionally, Sprague [17] reported adequate control of common chickweed with mesosulfuron or pyroxsulam, but inadequate control of common chickweed with 2,4-D + MCPA or clopyralid in winter wheat under Michigan, USA environmental conditions. In other crops, atrazine, dicamba, mesotrione, diflufenzopyr/dicamba, dicamba/atrazine, bromoxynil + atrazine, prosulfuron/dicamba, primisulfuron/dicamba, and 2,4-D/atrazine, applied POST, controlled common chickweed $99 \%$ in corn [7].

\section{Conclusion}

Based on these results, fluroxypyr/bromoxynil/MCPA, pyrasulfotole/bromoxynil, pyrasulfotole/bromoxynil/fluroxypyr, pyrasulfotole/bromoxynil/thiencarbazone, pyrasulfotole/ bromoxynil/thiencarbazone + MCPA ester, tolpyralate and fluroxypyr/halauxifen + MCPA EHE, applied POST, provide inadequate control of common chickweed in winter wheat. Fluroxypyr/halauxifen + pyroxsulam + MCPA EHE, applied POST, provides good control of common chickweed in winter wheat. Herbicides that included tribenuron including thifensulfuron/tribenuron, thifensulfuron/tribenuron + MCPA ester, thifensulfuron/tribenuron + fluroxypyr + MCPA ester, tribenuron + thiencarbazone, and tribenuron + thiencarbazone + MCPA ester, applied POST, provide excellent control of common chickweed in winter wheat. However, common chickweed biotypes that are resistant to Group 2 herbicides including tribenuron have been found in many parts of North America [18] [19], but there is no report of the existence of these resistant biotypes in Ontario. However, the potential spread of these biotypes into Ontario will limit herbicide options for the control of Group 2-resistant common chickweed. Future research should focus on crop rotation and other weed control strategies including herbicide mixtures with multiple sites of action for common chickweed control in winter wheat under Ontario environmental conditions.

\section{Acknowledgements}

The authors gratefully acknowledge Lynette Brown for her technical contributions to this project. Funding for this project was provided in part by the Grain Farmers of Ontario (GFO) and the Canadian Agricultural Partnership (CAP) program of the Agricultural Adaptation Council (AAC).

\section{Conflicts of Interest}

The authors declare no conflicts of interest regarding the publication of this paper.

\section{References}

[1] Ontario Ministry of Agriculture, Food and Rural Affairs (2019) Area, Yield, Pro- 
duction and Farm Value of Specified Field Crops (Imperial and Metric Units). http://www.omafra.gov.on.ca/english/stats/crops/index.html

[2] Brandt, S.A. (1992) Zero vs. Conventional Tillage and Their Effects on Crop Yield and Soil Moisture. Canadian Journal of Plant Science, 72, 679-688.

https://doi.org/10.4141/cjps92-084

[3] Jug, D., Durđevic, B., Birkas, M., Brozovic, B., Lipiec, J., Vukadinovic, V. and Jug, I. (2019) Effect of Conservation Tillage on Crop Productivity and Nitrogen Use Efficiency. Soil and Tillage Research, 194, Article ID: 104327. https://doi.org/10.1016/j.still.2019.104327

[4] Radke, J.K., Dexter, A.R. and Devine, O.J. (1985) Tillage Effects on Soil Temperature, Soil Water, and Wheat Growth in South Australia. Soil Science Society of America Journal, 49, 1542-1547.

https://doi.org/10.2136/sssaj1985.03615995004900060042x

[5] Defelice, M.S. (2004) Common Chickweed, Stellaria media (L.) Vill._"Mere Chicken Feed". Weed Technology, 18, 193-200. https://doi.org/10.1614/0890-037X(2004)018[0193:CCSMLV]2.0.CO;2

[6] Inderjit, K. and Dakshini, K.M.M. (1998) Allelopathic Interference of Chickweed, Stellaria media with Seedling Growth of Wheat (Triticum aestivum). Canadian Journal of Botany, 76, 1317-1321. https://doi.org/10.1139/b98-159

[7] Cowbrough, M. (2005) Chickweed, Common (Stellaria media). Ministry of Agriculture, Food and Rural Affairs, Guelph.

http://www.omafra.gov.on.ca/english/crops/field/weeds/common_chickweed.htm

[8] Anonymous (2019) Common Chickweed (Stellaria media). http://www.better-lawn-care.com/common-chickweed.html\#axzz61myp3uIb

[9] Anonymous (2019) Winter Annual Weeds. https://www.missouribotanicalgarden.org/gardens-gardening/your-garden/help-for -the-home-gardener/advice-tips-resources/pests-and-problems/weeds/winter-annu al.aspx

[10] Farahbakhsh, A., Murphy, K.J. and Madden, A.D. (1987) The Effect of Weed Interference on the Growth and Yield of Wheat. Proc. Br. Crop Prof. Conf., 3, 955-961.

[11] Vrabel, T.E. (1987) Effect of Fall Weed Control on the Yield of Winter Wheat. Proceeding of Northeastern Weed Science Society, Vol. 41, 55-58.

[12] Tomlinson, J.A. and Carter, A.L. (1970) Studies on the Seed Transmission of Cucumber Mosaic Virus in Chickweed (Stellaria media) in Relation to the Ecology of the Virus. Annals of Applied Biology, 66, 381-386. https://doi.org/10.1111/j.1744-7348.1970.tb04617.x

[13] Ontario Ministry of Agriculture, Food and Rural Affairs (2018) Guide to Weed Control. Publication 75. OMAF, Toronto, $355 \mathrm{p}$.

[14] Zadoks, J.C., Chang, T.T. and Konzak, C.F. (1974) A Decimal Code for the Growth Stages of Cereals. Weed Research, 14, 415-421. https://doi.org/10.1111/j.1365-3180.1974.tb01084.x

[15] Statistical Analysis Systems (2014) The SAS System, Version 9. Statistical Analysis Systems Institute, Cary, 4.

[16] Penn State Extension (2014) Chickweed, Roughstalk Bluegrass Control in Winter Wheat and Barley. Pennsylvania State University Extension, State College. https://www.no-tillfarmer.com/articles/2462-chickweed-roughstalk-bluegrass-contr ol-in-winter-wheat-and-barley

[17] Sprague, C. (2019) Herbicide Options for Weed Control in Winter Wheat. Michi- 
gan State University Extension, East Lansing.

https://www.canr.msu.edu/news/herbicide_options_for_weed_control_in_winter_w heat_things_to_consider

[18] Heap, I. (2019) The International Survey of Herbicide Resistant Weeds. http://www.weedscience.org

[19] O’Donovan, J.T., Jeffers, G.M., Maurice, D. and Sharma, M.P. (1994) Investigation of a Chlorsulfuron-Resistant Chickweed [Stellaria media (L.) Vill.] Population. Canadian Journal of Plant Science, 74, 693-697. https://doi.org/10.4141/cjps94-125 